\title{
併用落绪数之相互作用の頻度調查 （1）外来処方せんについて
}

\author{
中村順吉, 煙山信夫, 赤坂善昭, 川口裕幹, 沢田東子, \\ 松坂久美子, 高橋勝雄, 松浦牧雄, 藤倉守寿 \\ 岩手医科大学附属病院薬郕部*
}

\section{Number of Combined Drugs on Prescriptions for Outpatients and Their Interactions}

\author{
JUNKICHI NAKAMURA, NOBUO KemUYAMA, YOSHIAKI AKasaKa, HiRomoto \\ KaWAGUCHI, TOHKo SAWAdA, KUMIKo MatSUZaKa, Katsuo \\ TAKAHASHI, MAKIO MATSUURA, and MORIJU FUJIKURA \\ Department of Pharmacy, Iwate Medical Academy Hospital*
}

(Received December 17, 1980)

\begin{abstract}
The relationship between the number of combined drugs on prescriptions for outpatients and frequency of their interactions was studied. The investigation was made from Monday through Friday. The combination of 1 to 4 drugs accounted for $62.3 \%$, including that of 3 drugs which composed the largest part of $17.3 \%$. The average number of combined drugs was largest, 5.2 , at the department of internal medicine. The interactions were observed in $3.8 \%$ of the total prescriptions. They were caused by contraindications in $6.1 \%$, inappropriate combinations in $8.2 \%$, and caution for combination in $85.7 \%$. The rate of interactions was highest, $44.9 \%$, at the department of psychiatry, followed by $45.9 \%$ in 3 divisions of internal medicine.

Some cases of contraindications were thus noted in the study, but it was found that most of the doctors take precaution against interactions in prescribing drugs for combination. In the future, information for doctors and instruction of patients in using drugs must be promoted on the basis of extensive investigation of interactions of drugs on prescriptions for inpatients and parenteral preparations.
\end{abstract}

\section{目的}

薬物の相互作用に関する認識が高まるにしたがい，医 薬品の併用調查は年々增加している.この併用薬の実態 を調査し, 把握しておくことは, その病院診療科の投薬 傾向や医薬品の副作用予知のため, またクリニカルファ 一マシーの基礎資料としてもきわめて重要と思われる.

著者らは薬剤の服用が患者自身にまかされている外来部 門について，特に重要と考元，当院に批ける外来患者の 処方せんを調査検討したので報告する.

\section{铎查方法}

当院の外来処方は, そのほ之んどが 1 週間以上の投与 であることから，表 1 と示すよ5に調查期間は，昭和 53

* 盛岡市内丸 19-1；19-1, Uchimaru, Morioka-shi, 020 Japan
年 5 月22日（月）から5 月27日（土）での 1 週間分（実 働日数 5.5 日分) とし, その間に当院薬剤部で受付けた 全外来処方せん 2,595 枚を対象とした.これを各科毎に， (1)内服薬のみ投薬, (2)内服薬十外用薬投薬に分類し，そ れらの併用薬剤数および相互作用の碩度を調查した. 相 互作用のチェックは, 主として石橋らの「図説薬物の相 互作用」および小沢らの「薬物相互作用早見」(改訂版) を用いて行った。

表 1. 調查方法

\begin{tabular}{|c|c|}
\hline 調 查 期間 & S 53.5.22 S 53.5.27 (5.5日間) \\
\hline $\begin{array}{l}\text { 調 查 対 象 } \\
\text { 調查処方せ }\end{array}$ & $\begin{array}{l}\text { 岩手医科大学附風病院 外来処方せん } \\
\text { (枚数) } 2,595 \text { 枚 }\end{array}$ \\
\hline 参考文献 & $\begin{array}{l}\text { 小沢らの莱物相互作用評価早見表, 石橋ら } \\
\text { の四説薬物の相互作用, その他 }\end{array}$ \\
\hline
\end{tabular}




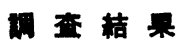

\section{1. 併用萃却数の分布}

全処方せんの併用薬剤数と累積度数の分布を示したも のが図 1 である. 1 剂から 4 剂の併用が全体の62.3\%を 占め, とりわけ 3 剂併用が最も多く $17.3 \%$, 次いで 2 剂 併用が $16.9 \%$ ，以下グラフに示す順である. 5 剤以上 の併用になると枚数の急激な減少傾向が見られる.最高 併用薬剂数は14剤で 3 枚あった。

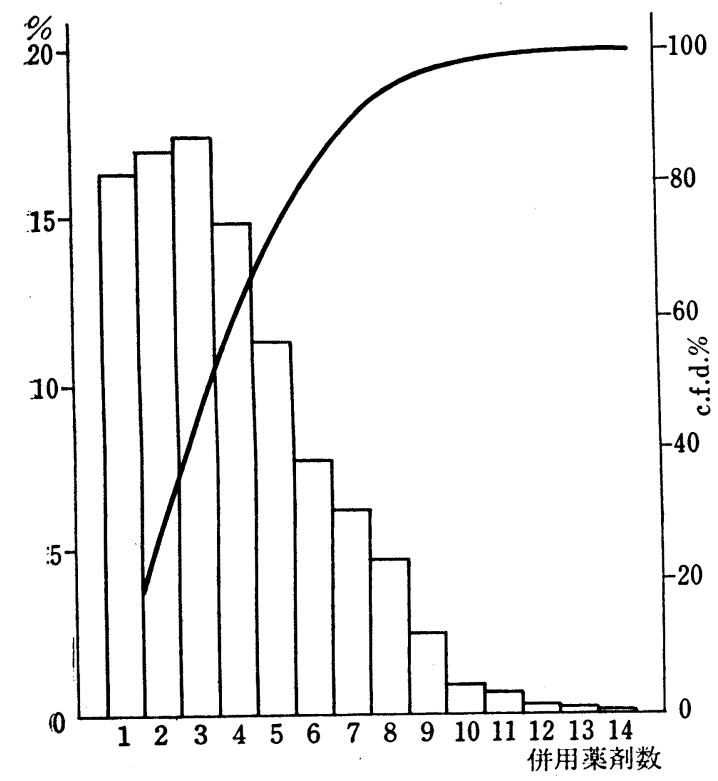

c.f.d : cumulative frequency distribution 図 1. 全処方せんの併用薬剤数分布(内服薬)

\section{2. 科别による平均併用莱咕数}

科別による平均併用薬剂数をみると，(1)内服薬のみ投 与では図 2 に示すように消化器系内科で最も多く6.3剂, 次いで放射線科 4.8 㶡, アレルギー内科 4.6 珮の順であ わ，心臓外科，耳鼻科，婦人科の 3 科は少なく平均 2 剤 併用であった．また，(2)内服薬十外用薬投薬では内服薬 のみ投薬とくらへ，因3の棒グラフの白い部分が示す通 り, 軟高剂, 外用液剂が多く処方される皮層科で 3.2 剂か ら 4.4 剂と最も多く增加し, 点眼薬が処方される眼科で 2.8 剂から 3.6 剂, パップ剂が処方される整形外科で 3 剤から 3.6 剂と增加が見られたが，他の科では大きな增 加はみられなかった。

\section{3. 併用薬都数と相互作用紫度}

困 4 は併用薬剤数と相互作用頻度との関係を示したも のである. 各併用薬剤数毎の枚数の棒グラフ黒ぬき部分 は各併用薬剂枚数毎の相互作用のみられた処方せんの枚

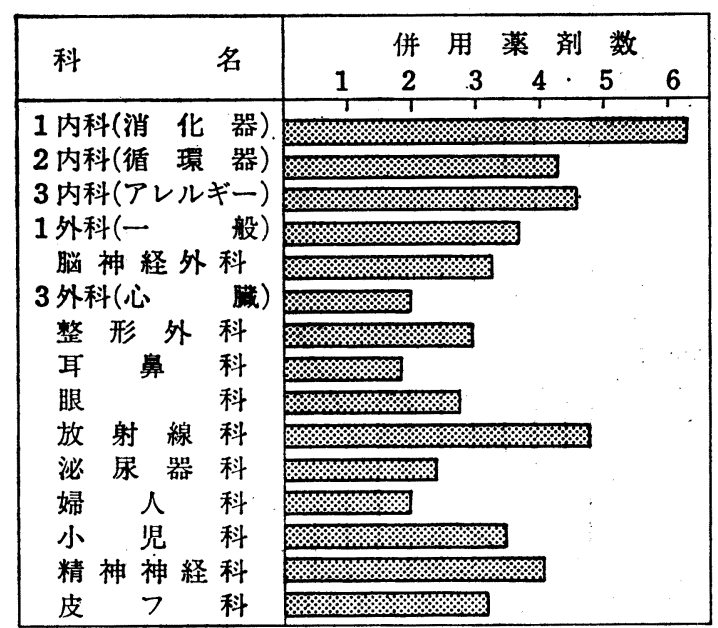

因 2. 科別による平均併用薬剂数（内用薬）

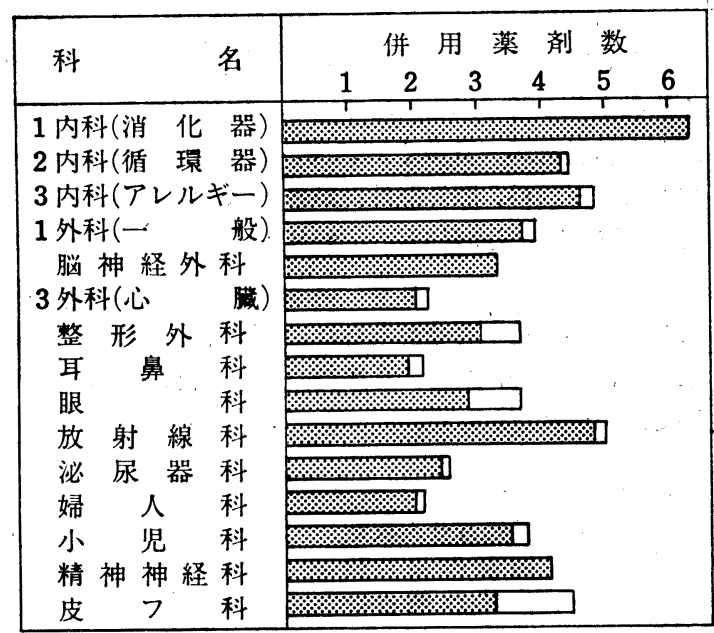

因 3. 科別による平均併用薬剤数（内用薬十 外用薬)

数を示し，また各併用薬剂数毎の相互作用頻度は線グラ フで示している.このことから併用薬剤数が増加すると 相互作用の組み合せの出現する頻度が多くなることを示 している.

\section{4. 科别による相互作用頻度}

表 2 に示すよう調查した処方せん 2,595 枚のうち, 相 互作用のみられた処方せんは98枚で全処方せんの $3.8 \%$ であり，また薬効別毎の相互作用の組み合せで分類する と28件であった.

科別による相互作用の割合,および頻度をみると,精神 科44枚 (44.9\%) で最す多く, 次いで循環器系内科25枚 $(25.5 \%)$, アレルギー内科 12 枚 $(12.2 \%)$, 消化器系 内科 8 枚 $(8.2 \%)$, 脳神経外科, 整形外科が各々 3 枚 


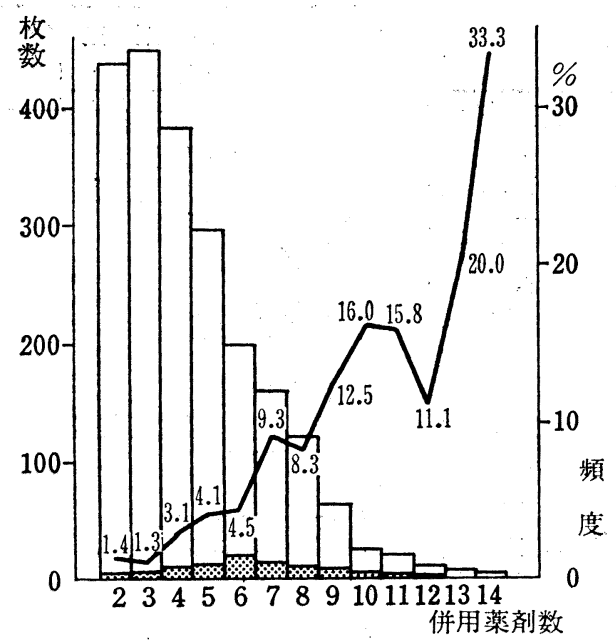

図 4. 併用薬剂数と相互作用頻度

(3.1\%), 小児科 2 枚 (2\%), 一般外科 1 枚 (1\%)の順 であり，精神科と内科系 3 科で相互作用を有する処方せ ん枚数全体の $90.8 \%$ を占めている. 相互作用の出現する 頻度も精神科が一番多く $17.1 \%$, 循環器系内科 $8.9 \%$, フレルギー内科, 脳神経外科が各々 $3.9 \%$, 整形外科 $2.4 \%$, 消化器系内科 $2 \%$, 一般外科, 小児科が各々 0.8 \%であり，16診療科のうち，以上の 8 科からの処方せん で相互作用の組み合せがみられ，心臓外科，皮虚科，泌 尿器科, 婦人科, 眼科, 耳鼻科, 放射線科, 麻酔科の 8 科ではみられなかった。

表 2. 科別による相互作用頻度

$\begin{array}{lr}\text { 総処方せん枚数 } & 2,595 \text { 枚 } \\ \text { 相 互 作 用 枚数 } & 98 \text { 枚 } \\ \text { 相 互 作 用 件数 } & 28 \text { 枚 }\end{array}$

\begin{tabular}{|c|c|c|c|}
\hline 科 & 枚数 & $\%$ & 頻度\%（処方枚数） \\
\hline 1 内科（消化器） & 8 & 8.2 & $2.0(405)$ \\
\hline 2 内科 (循環器) & 25 & 25.5 & $8.9(280)$ \\
\hline 3 内科 (フレルギー) & 12 & 12.2 & $3.9(308)$ \\
\hline 1 外科（一 般） & 1 & 1.0 & 0.8 (125) \\
\hline 脳神経外科 & 3 & 3.1 & $3.9(76)$ \\
\hline 整形外科 & 3 & 3.1 & 2.4 (123) \\
\hline 小 児 科 & 2 & 2.0 & $0.8(262)$ \\
\hline 精神神経科 & 44 & 44.9 & 17.1 (257) \\
\hline 計 & \begin{tabular}{|l|l}
98 & 1 \\
\end{tabular} & 100.0 & $3.8(2,595)$ \\
\hline
\end{tabular}

\section{5. 相互作用例}

薬効別相互作用28件，98枚の らち，併用禁忌 1 件 6 枚 $(6.1 \%)$, 併用不適 4 件 8 枚 (8.2\%), 併用慎重23件 84 枚 $(85.7 \%)$ であった。これらの例は表 3,4,5 に示す通 りである。
表 3. 併用禁忌の例 (6.1\%)

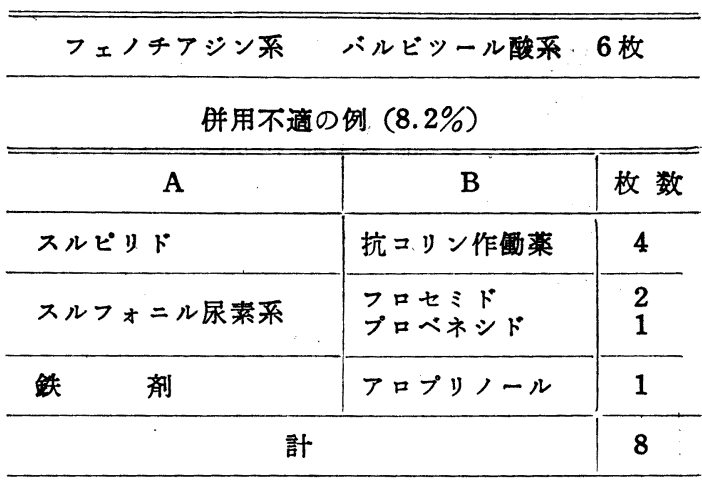

表 4. 併用慎重の例（1） $85.7 \%$

\begin{tabular}{|c|c|c|}
\hline A & B & 枚 数 \\
\hline ジギタリス類 & $\begin{array}{l}\text { フロセミド } \\
\beta \text { 遮断薬 } \\
\text { チフジド系 } \\
\text { メトクロブラミト }\end{array}$ & $\begin{array}{l}14 \\
3 \\
2 \\
1\end{array}$ \\
\hline スルフォニル尿素系 & 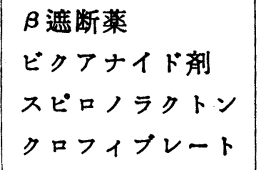 & $\begin{array}{l}1 \\
2 \\
1 \\
2\end{array}$ \\
\hline バルビッール酸系 & $\begin{array}{l}\text { ペンゾジアゼピン系 } \\
\text { 催眠鎮静剤 } \\
\text { 抗ヒスタミン風 }\end{array}$ & $\begin{array}{l}12 \\
3 \\
6\end{array}$ \\
\hline \multicolumn{2}{|c|}{ 計 } & 47 \\
\hline
\end{tabular}

表 5. 併用慎重の例 (2)

\begin{tabular}{|c|c|c|}
\hline A & B & 枚 数 \\
\hline フェノチアシシン系 & $\begin{array}{l}\text { アトロピン様薬 } \\
\text { 降 圧 羭 } \\
\text { ペンソジアゼピン系 }\end{array}$ & $\begin{array}{l}2 \\
3 \\
8\end{array}$ \\
\hline ペンソジアセヒピ系 & $\begin{array}{l}\text { 催眠鎮静剤 } \\
\text { 三環系抗うつ薬 }\end{array}$ & $\begin{array}{l}7 \\
9\end{array}$ \\
\hline 副腎皮質ステロイド剤 & $\begin{array}{l}\text { テトラサイクリン系 } \\
\text { サリチル酸系 } \\
\text { ハルビッール酸系 }\end{array}$ & $\begin{array}{l}1 \\
3 \\
1\end{array}$ \\
\hline ペニシリン系 & $\begin{array}{l}\text { エリスロマイシン } \\
\text { サリチル酸系 }\end{array}$ & $\begin{array}{l}1 \\
1\end{array}$ \\
\hline チフシド系 & スピロノラクトン & 1 \\
\hline \multicolumn{2}{|l|}{ 計 } & 37 \\
\hline
\end{tabular}


まず併用禁忌の「バルビッール酸系催眠剤」と「フェ ノチアジン系トランキライザー」1) の併用であるが，処方 医への問い合せでは，相互作用を十分承知の上で，患者 の異常な興奮時に鎮静のために服用量を十分注意しなが ら，主として頓服薬としてやむを得ず投与しているとの ことであった。

次に併用不適の例であるが，「スルピリド」と「抗コ リン作働薬」》4 枚,「スルフォニール尿素系経口血糖降 下凨」と「フロセミド」,2) 2 枚,「スルフォニール尿素系 経口血糖降下片」と「プロベネシド」1) 1 枚，「鉄剤」と 「アロプリノール」リの併用が 1 枚あった.

\section{6. 相互作用の多くみられた例}

相互作用の多くみられた上位 5 件を示したるのが表 6 である.これらはいずれる併用慎重の例であった。

表 6. 薬物相互作用例 $(3.8 \%)$

\begin{tabular}{|c|c|c|c|}
\hline $\mathbf{A}$ & B & 枚数 & $\%$ \\
\hline シギタリス類 & フロセミド & 14 & 14.3 \\
\hline バルビッール酸系 & ペンゾジアゼピン系 & 12 & 12.2 \\
\hline ペンソジアゼピン系 & $\begin{array}{l}\text { 三環系抗うつ成 } \\
\text { フェノチフシン系 } \\
\text { 催眠鎮静剤 }\end{array}$ & $\begin{array}{l}9 \\
8 \\
7\end{array}$ & $\begin{array}{l}9.2 \\
8.2 \\
7.1\end{array}$ \\
\hline \multicolumn{2}{|c|}{ その他の組み合わせ } & 48 & 49.0 \\
\hline \multicolumn{2}{|c|}{ 計 } & 98 & 100.0 \\
\hline
\end{tabular}

「ジギタリス類」と「フロセミド」1,2)の併用が一番多 く14枚 (14.3\%) で, 主として循環器系内科からの処方 であったが，そのほとんどの処方がK剤を併用してお ク，処方医との話し合いでも，相互作用を承知のうえ患 者の十分な観察，検査など行いながらの慎重な投与であ ることがわかった。

次いで多いのが「バルビッール酸系催眠㶡」と「ベン
ゾジアゼピン系トランキライザー $\rfloor^{1,2} 12$ 枚 (12. 2\%), 「ベンゾジアゼピン系トランキライザー」と「三環系抗う つ剂 $\rfloor^{1,2)} 9$ 枚 $(9.2 \%)$,「フェノチアジン系トランキライ ザー」と「ベンゾジアゼピン系トランキイザー」1,2) 8 枚 (8.2\%), 「ベンゾジアゼピン系トランキライザー」と 「催眠鎮静剤」”が 7 枚 (7.1\%)であり，この 4 件の併用 処方はほとんどが精神科からの処方であり，この科への 問い合せです相互作用の増強作用を目的としての投与で あることがわかった. 薬効別相互作用例28件のうち，こ れら上位 5 件で相互作用を有する処方せん枚数の $51 \%$ \% 占めていた。

\section{結果と考荥}

今回調査した外来処方せん 2,595 枚のうち, 相互作用 のみられたもの98枚 (28 件) で全体の $3.8 \%$ であり，相 互作用のみられたもののらち, 併用禁忌 6 枚 (6.1\%), 併用不適 8 枚 (8.2\%), 慎重投与 84 枚 (85.7\%) であっ た. 併用禁忌があったことは問題ではあるが，この併用 例も含めほとんどの処方医は各々の専門分野での相互作 用は十分認識した上で，しかも患者の病状の観察, 検査 など行いながら慎重に投与していることがわかった。今 後は入院処方せん，注射薬などの相互作用も調查検討 し，医師側への情報を提供しながらより良い医療努め なければならないと思われる。

的辟 最後に今回の相互作用の調查検討にあたり，こ 指導をいただいた岩手医科大学第二内科，高橋栄司先生 に深く感謝いたします。

\section{参考 文 献}

1) 石橋丸応: 因説薬物の相互作用, 南山堂, 1976.

2）米国薬郕師会編：医薬品相互作用とその評価（新 訂第 2 版), 楽事日報社, 1978 .

3）小沢 光: 荘物相互作用早見 (改訂版), 薬事新 報社, 1977 . 